\title{
HUBUNGAN MORFOMETRI AMBING TERHADAP PRODUKSI SUSU KUDA DI DAERAH BIMA NUSA TENGGARA BARAT
}

\section{RELATIONSHIP BETWEEN MORPHOMETRY OF UDDER MARES AND MILK PRODUCTION IN BIMA DISTRICT WEST NUSA TENGGARA}

\author{
Mujahid ${ }^{1)}$, Imam Mustofa ${ }^{2)}$, Benjamin Chr Tehupuring ${ }^{3)}$, Tjuk Imam Restiadi4), \\ Hana Eliyani ${ }^{5)}$, Hermin Ratnani ${ }^{6}$ \\ ${ }^{1)}$ Student, ${ }^{2,4,6)}$ Departement of Veterinary Reproduction, \\ ${ }^{3,5}$ Departement of Veterinary Anatomy \\ Faculty of Veterinary Medicine, Universitas Airlangga \\ *Corresponding author: email: imam.mustofa@ymail.com
}

\begin{abstract}
Objective from this research was to determine the relationship of udder morphometry which consists of the height of the front udder, the height of the rear udder and the circumference ofudder on milk production in the Bima District of West Nusa Tenggara. One of ways to choose a good lactational mare is to pay attention at the shape of the part external body which is udder. The sample had used 32 mares that were in lactation period. Milk production has been measured from the average milk production per day in the lactation period. Milking process in Bima District, West Nusa Tenggara has done in three to four times a day in the span of four to five hours per day. Body length had been measured from os thoracalis to os coxae, chest circumference had been measured from os vertebrae thoracalis to os thoracalis, posterior abdomen of pelvic to os pelvis and the last of os lumbar vetebrae. The research design in this study was survey on every wild mares rancher. Data that has been collected and processed using Multiple Regression with SPSS program version $23^{\text {th }}$. The result showed that there was a strong relationship between height of rear udder and udder circumference to milk production with back udder with height coefficient of $0.21(\mathrm{P}<0.05)$ and udder circumference was $0.11(\mathrm{P}<0.05)$ and equation in $\mathrm{Y}=2.423-0.398 \mathrm{LA}+0.793 \mathrm{TAB}$. However, there is no significant relationship between the height of the front udder and milk production.
\end{abstract}

Keywords: morphometry, udder mares, milk production

\section{Pendahuluan}

Kuda poni sandel di Pulau Sumbawa merupakan kuda lokal asli Indonesia yang berasal dari persilangan kuda lokal (Sandelwood pony) dengan bangsa kuda Arab atau Thoroughbred (Lailidkk, 2014). Secara umum kuda di Pulau Sumbawa memiliki beberapa kegunaan bagi masyarakat. Dalam bidang ekonomi, kuda Sumbawa banyak di perjual belikan hingga keluar daerah Pulau Sumbawa. Dalam bidang kebudayaan kuda Sumbawa memiliki fungsi yaitu sebagai kuda pacu, yang merupakan salah satu kegiatan kebudayaan unik yang ada di Pulau Sumbawa, kegunaan lain yaitu sebagai penghasil susu (Pertiwi, 2007).

Susu kuda Sumbawa merupakan salah satu susu murni hasil perahan kuda liar yang diternakan petani organik di pulau
Sumbawa, Nusa Tenggara Barat, Indonesia. Masyarakat menganggap susu ini mempunyai banyak manfaat dan keunggulan, Susu kuda Sumbawa memiliki komposisi susu lebih mendekati air susu ibu (ASI) jika dibandingkan dengan susu sapi (Saragih dkk, 2013).

Komposisi susu mamalia bervariasi dan sangat luas tergantung dari faktor-faktor genetik, fisiologis, nutrisi serta lingkungan, Komposisi kimia susu juga dapat dipengaruhi oleh faktor spesies, breed,individu, status nutrisi dan periode laktasi (Malancarne et al, 2002).

Susu kuda Sumbawa mempunyai keistimewaan yaitu ketahanannya dalam kontaminasi mikroorganisme pembusuk sehingga susu ini lebih tahan lama (Laili dkk, 2014). Susu kuda Sumbawa dapat digunakan se- 
bagai alternatif pengganti ASI, terutama bagi masyarakat pedesaan yang susah mencari susu bubuk atau susu formula bayi. Keunggulan susu kuda dibandingkan dengan susu ternak lainnya yaitu susu kuda tidak mengalami penggumpalan dan kerusakan meskipun tidak dipasteurisasi. Selain itu susu kuda juga dapat menyembuhkan berbagai macam penyakit seperti penyakit jantung, hipertensi, seperti paru-paru basah, bronchitis, tifus dan sebagainya (Hakim dkk, 2013).

Setiap bangsa kuda mempunyai sifat karakteristik sendiri terhadap kualitas dan kuantitas produksi dan komposisi susu, sedangkan produksi susu dan komposisi susu di pengaruhi oleh konsumsi pakan (Legowo, 2002). Sudono dkk. (2003), penambahan pakan untuk ternak perah yang sedang mengalami penurunan produksi tidak dapat meningkatkan produksi pemerahan sehingga tidak ekonomis, namun nutrisi dari penambahan pakan tersebut dapat digunakan untuk memperbaiki kondisi tubuh yang mengalami penurunan bobot badan, sehingga tidak akan mengganggu pada periode estrus berikutnya.

Kuda persilangan impor dan lokal mampu memproduksi susu sebanyak $12 \mathrm{~kg}$ dengan puncak produksi $14,5 \mathrm{~kg}$ dan $10 \mathrm{~kg}$ pada masa akhir latasi. Kuda Indonesia hanya mampu menghasilkan susu maksimal 4 liter per hari, sedangkan kuda Sumbawa mampu memproduksi susu sekitar 3 liter per hari (Dharmojono, 1998).

Masa laktasi merupakan masa ternak sedang memproduksi susu setelah melahirkan sampai memasuki masa kering. Masa laktasi berkisar 4-6 bulan (Gore et al., 2008).

Kelenjar kambing ternak betina mulai berkembang pada masa fetalis. Ambing kuda sudah terlihat sejak lahir namun pada saat kuda betina tumbuh dewasa, ambingnya membesar sebanding dengan besarnya tubuh (Padmadewi, 1993). Persiapan kelenjar ambing untuk proses laktasi menjelang akhir kebuntingan dipengaruhi oleh perubahan hormon spesifik. Pada banyak spesies, konsentrasi progesteron dan estrogen tinggi selama kebuntingan sehingga menginisiasi perkembangan alveolar lobus ambing. Peningkatan progesteron dan estrogen ditandai dengan peningkatan ukuran kelenjar ambing. Secara spesifik progesteron meng- hambat produksi susu namun saat kelahiran konsentrasi progesteron mengalami penurunan sehingga berefek pada peningkatan produksi susu (Heidler et al., 2003).

Kuda memiliki dua ambing susu pada bagian abdomen. Setiap ambing memiliki dua duktus dan dua kisterna ambing, yang masing-masing berhubungan dengan kisterna kelenjar yang terpisah juga sistem duktus dan alveoli (Frandson, 1992; Akers and Denbow, 2008). Intensitas pengambilan susu kuda yang tinggi dapat memacu kuda memproduksi susu yang lebih banyak dibanding kuda yang pertama kali diambil susunya (Poole, 1982) dan (Carruthers et al, 1993) menyebutkan pemerahan tiga kali sehari meningkatkan hasil sampai sekitar $10 \%$ dan memerah susu sekali sehari berkurang hingga $20 \%$. Selain itu dalam pengambilan susu kuda dibutuhkan ketrampilan yang baik, mencakup penguasaan kuda dan pengenalan yang baik tentang tingkah laku kuda.

Proses pengeluaran susu pada hewan atau milk let down dipengaruhi oleh hormon oksitoksin yang meningkat pada masa akhir kebuntingan dan masa laktasi (Knigth, 1998). Faktor yang memengaruhi sekresi hormon oksitoksin adalah stimulasi ambing dan rangsangan isapan susu dari anak kuda dan pemerahan atau pengeluaran susu secara kontinu (Akers, 2002). Pemerahan susu kuda secara maksimal dan kontinue akan memudahkan proses pengeluaran susu saat pengambilan susu kuda. Pada kuda, sekitar $80 \%$ kasus puncak oksitosin terjadi hanya setelah peningkatan tekanan intramamari dan pada sebagian kasus tekanan intramamari meningkat tanpa ada perubahan dalam pengeluaran oksitosin (Deichsel dan Aurich, 2005).

Berdasarkan uraian diatas, maka perlu dilakukan penelitian mengenai hubungan morfometri ambing kuda Sumbawa berpengaruh pada produksi susu.

\section{Materi Dan Metode Penelitian \\ Tempat dan Waktu Penelitian}

Penelitian ini dilaksanakan di Daerah Kabupaten Bima, Nusa Tenggara Barat, Dimulai pada bulan April-Mei 2018.

\section{Alat dan Bahan Penelitian}

Alat yang digunakan dalam penelitian ini adalah pita ukur dalam satuan $\mathrm{cm}$ se- 
panjang $150 \mathrm{~cm}$, alat tulis untuk mencatat hasil pengukuran. Bahan utama yang digunakan dalam penelitian ini adalah 32 ekor Kuda Perah Betina yang diperoleh di Daerah Kabupaten Bima, Nusa Tenggara Barat.

\section{Metode Penelitian}

Pengukuran lingkar ambing dilakukan dengan cara melilitkan pita ukur dari ujung pangkal ambing yang dekat dengan lekuk intermamaria (intermammary grove) yang dibagaikan (titik C) melingkar keujung pangkal ambing (titik C) kembali. Pengukuran tinggi ambing dilakukan dengan menggunakan pita ukur, diukur dari pangkal ambing atas dekat ambing (titik A) sampai bagian ambing bawah yaitu streak canal (titik B). Pengukuran ambing dari sisi depan dan sisi belakang dilakukan sama dengan cara pengukuran tinggi ambing, seperti pada Gambar 1.

\section{Analisis Data}

Data hasil penelitian untuk mengetahui hubungan Morfometri Ambing terhadap produksi susu Kuda perah di gunakan Regresi Berganda dengan program SPSS.

\section{Hasil Dan Pembahasan}

Pengambilan data morfometri ambing dengan sampel 32 ekor kuda Sumbawa dilakukan satu kali selama penelitian. Variabel yang diamati antara lain morfometri ambing (tinggi ambing depan, tinggi ambing belakang, lingkar ambing) dalam sentimeter., serta produksi susu yaitu volume susu Kuda perah dalam liter.

Data morfometri ambing dan produksi susu yang dapat dilihat pada Tabel 1 .

Hubungan Tinggi Ambing Belakang dan Lingkar Ambing terhadap Produksi Susu dapat dilihat pada Tabel 2. Tabel 2 memperlihatkan koefisien signifikansi Tinggi Ambing Belakang dan Lingkar ambing $0,28(\mathrm{p}<0,05)$ yang berarti bahwa kedua variabel tersebut memiliki hubungan yang nyata dengan produksi susu.

Pada Tabel 3 menunjukkan bahwa didapat koefisien keeratan tinggi ambing belakang $0.21(\mathrm{p}<0.05)$ dan lingkar ambing 0.11 ( $\mathrm{p}<0.05$ ) yang berarti bahwa tinggi ambing belakang dan lingkar ambing

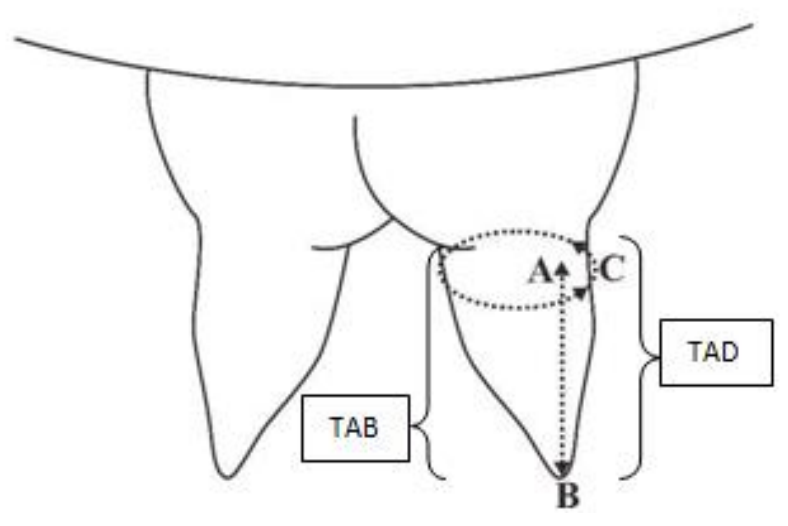

Gambar 1. Pengukuran Puting.

Tabel 1. Morfometri Ambing kuda (Tinggi Ambing Depan,Tinggi Ambing Belakang, Lingkar Ambing).

\begin{tabular}{ccc}
\hline Variabel & Rentangan & Rata-rata \pm SD \\
\hline TAD & $4-6 \mathrm{~cm}$ & $4,42 \pm 0,72$ \\
TAB & $4-6 \mathrm{~cm}$ & $4,42 \pm 0,72$ \\
LA & $4,5-10 \mathrm{~cm}$ & $6,00 \pm 1,60$ \\
PRODUKSI SUSU & $1,35-7$ liter & $3,54 \pm 1,06$ \\
\hline
\end{tabular}

\footnotetext{
Keterangan : $\mathrm{TAD}=$ tinggi ambing depan

$\mathrm{TAB}=$ tinggi ambing belakang

LA $=$ lingkar ambing
} 
Tabel 2. Nilai Koefisien Signifikansi Morfometri Ambing terhadap Produksi Susu Kuda.

\begin{tabular}{cccccc}
\hline Model & $\begin{array}{c}\text { Sum of } \\
\text { Squares }\end{array}$ & Df & Mean Square & F & Sig. \\
\hline Regresion & 7.694 & 2 & 3.847 & 4.075 & 0.028 \\
Residual & 27.381 & 29 & 0.944 & & \\
Total & 35.076 & 31 & & & \\
\hline
\end{tabular}

Tabel 3. Nilai Koefisien Keeratan Tinggi Ambing Depan. Tinggi Ambing Belakang dan Lingkar Ambing.

\begin{tabular}{|c|c|c|c|c|c|}
\hline \multirow[t]{2}{*}{ Model } & \multicolumn{2}{|c|}{$\begin{array}{l}\text { Unstandarized } \\
\text { Coefficients }\end{array}$} & \multirow{2}{*}{$\begin{array}{l}\text { Standardized } \\
\text { Coefficients } \\
\text { Beta } \\
\end{array}$} & \multirow[t]{2}{*}{$\mathbf{t}$} & \multirow[t]{2}{*}{ Sig. } \\
\hline & B & Std. Error & & & \\
\hline (Constant) & 2.423 & 1.098 & & 2.225 & 0.34 \\
\hline Lingkar Ambing & -0.398 & 0.146 & -0.599 & -2.727 & 0.11 \\
\hline $\begin{array}{l}\text { Tinggi Ambing } \\
\text { Belakang }\end{array}$ & 0.793 & 0.325 & 0.536 & 2.443 & 0.21 \\
\hline
\end{tabular}

memiliki keeratan yang nyata dengan produksi susu. Secara matematis hubungan antara tinggi ambing belakang dan lingkar ambing dengan produksi susu ditunjukkan oleh persamaan $\mathrm{Y}=2,423-0,398 \mathrm{LA}+$ $0,793 \mathrm{TAB}$.

Ada beberapa faktor yang dapat mempengaruhi produksi susu, di antaranya periode laktasi, masa laktasi, cara pemerahan, jumlah pakan, kualitas pakan dan faktor hormonal (Prihatminingsih dkk, 2015). Penelitian ini mengunakan sampel kuda yang diberikan pakan dan kualitas yang sama, cara pemerahan yang sama.Produksi susu terendah terjadi pada periode pertama karena pada saat itu organ tubuh serta endokrin yang memproduksi susu belum sempurna menghasilkan susu (Murtidjo, 1993). Produksi susu pada periode kedua merupakan produksi tertinggi karena organ tubuh dan endokrin sudah terbentuk sempurna. Pada kuda produksi susu setelah melahirkan sampai memasuki masa kering. Masa laktasi kuda adalah 150 hari, produksi susu kuda akan mencapai puncak pada hari ke-30 dan menurun setelah beberapa minggu, bulan laktasi (Anderson, 1914).

Hasil yang di dapat berdasarkan uji statistik terlihat mengunakan uji regresi berganda pada kuda perah dengan melihat hubungan antara tinggi mamae depan, tinggi mamae belakang dan lingkar mamae terhadap produksi susu. Data terdiri dari 32 sampel kuda perah dengan berbagai variasi sesuai keadaan yang ada di lapangan. Hasil Analisa uji regresi berganda di atas menunjukkan bahwa didapat koefisien keeratan tinggi ambing belakang 0.21 $(\mathrm{p}<0.05)$ dan lingkar ambing $0.11(\mathrm{p}<0.05)$ yang berarti bahwa tinggi ambing belakang dan lingkar ambing memiliki keeratan yang nyata dengan produksi susu.

Ternak yang sedang dalam masa kebuntingan mengalami pertumbuhan ambing yang cepat, dimana semakin besar ambing seekor ternak maka produksi susu yang dihasilkan akan semakin tinggi (Muzani dkk, 2015). Penelitian ini mengunakan sampel kuda perah yang memiliki ambing besar. Ambing berisi sekumpulan alveolus yang merupakan organ terkecil yang berperan dalam produksi susu.alveolus akan menjadi satu dan membentuk lobules dan di bungkus jaringan ikat disebut lobus. Setiap ambing memiliki sistim ductus yang berfungsi untuk menyalurkan susu yang dihasilkan alveolus ke tempat pengeluaran. Susu yang dihasilkan oleh alveolus akan disalurkan oleh sistim ductus ke sinus lacriferus dan gland system sebagai pengumpulan susu sebelum di sekresikan melalui putting. Semakin besar volume ambing semakin banyak pula produksi susu yang dihasilkan, maka produksi susu yang di perah semakin banyak (Muktar, 2006).

Pakan yang digunakan di Daerah Bima Nusa Tenggara Barat berupa hijauan rumput serta kosentrat berupa dedak. Pemberian pakan yang teratur serta perbandingan hijauan dan konsentrat menyebabkan produksi susu yang baik (Soryal et al., 2004). Pengaruh dari pakan terhadap produksi susu sebesar 70\% (Budiarsana dan Sutama, 2001). Pada saat pemerahan dan petugas yang memerah harus stabil untuk menghindari terjadinya kuda stress yang dapat 
menurunkan produksi susu (Sarwono 2002). Pemerahan di Daerah Bima Nusa Tenggara Barat dilakukan tiga sampai empat kali sehari dalam rentang waktu empat sampai lima jam dalam sehari dengan rata-rata produksi susu dua sampai lima liter.

\section{Kesimpulan}

Berdasarkan hasil penelitian dapat disimpulkan bahwa tinggi ambing belakang dan lingkar ambing kuda perah di Daerah Bima Nusa Tenggara Barat terdapat hubungan yang kuat dengan produksi susu.

\section{Daftar Pustaka}

Akers MR. 2002. Lactation and mammary gland. Iowa (US). Iowa State Press.

Anderson K. 1914. Nutrition management of pregnant and lactating mare. Department of Agriculture. Nebraska (USA): Institute of Agriculture and Natural Resources.

Budiarsana, I.G.M. dan I.K. Sutama. 2001. Efisiensi Produksi Susu Kambing Peranakan Etawa. Seminar Nasional Teknologi Peternakan dan Veteriner. 427-434.

Carruther VR. Davis SR. Bryant AM. Henderson HV. Morris CA and Copeman PJA. 1993. Response of Jersey and Friesian cows to once a day milking and prediction of response based on udder characteristic and milk composition. J Dairy Res. 60:1-11.

Dharmojono. 1998. Trend susu kuda liar. Infovet. 58: 29-30.

Fradson, R. D. 1993. Anatomi dan fisiologi ternak. Edisi keempat. Terjemahan. Gadjah Mada University Press. Yogyakarta.

Gore T. Gore P. Giffin JM. 2008. Veterinary Handbook: Horse owner's. New Jersey (US): Wiley Publishing. Hakim, N. S. I.K., I. P. Suada,dan Sampurna. 2013. Ketahanan Susu Kuda Sumbawa pada Penyimpanan Suhu Ruang Ditinjau Dari Total Asam, Uji Didih dan Warna. Indonesia Medicus Veterinus. 2(4): 369 - 374.

Heidler B. Parvizi N. Sauerwein H. Bruckmaier RM. Heintges U. Airich JE. Aurich C. 2003. Effects of lactation on metabolic and repro- ductive hormones in Lipizzaner mares. Domest Anim Endocrinol. 25:47-59.

Knigth CH. Peaker M. Wilde CJ. 1998. Local control of mammary development and function. Rev Reproduction. 3:104-112.

Knigth CH. Peaker M. Wilde CJ. 1998. Local control of mammary development and function. Rev Reproduction. 3:104-112.

Laili, F. N., E. Setiowati dan S.Iravati.2014 Susu Kuda Sumbawa Khas Indonesia Bahan Antibakteri Jerawat (Staphylococcus epidermis). Trad Med. J. 19(2): $74-79$.

Legowo AM. 2002. Sifat Kimiawi, Fisik dan Mikrobilogis susu. Diklat Kuliah. Fakultas Peternakan. Universitas Diponegoro. Semarang (ID):

Malancarne, M. F., A. Martuzzi, Summer dan P. Mariani. 2002. Protein dan Fat Composition of Mare's Milk: Some Nutrisional Remarks with Reference to Human and Cow's milk. Review. Internasional Daily Jurnal. 12 (3): 210230.

Malancarne, M. F., A. Martuzzi, Summer dan P. Mariani. 2002. Protein dan Fat Composition of Mare's Milk: Some Nutrisional Remarks with Reference.

Mukhtar, A. 2006. Ilmu Produksi Ternak Perah. Surakarta LPP UNS dan UNS Press. Surakarta.

Murtidjo, B.A. 1993 memilihara kambing sebagai ternak potong dan perah. Yogyakarta. Kanius.

Pertiwi, E. 2007. Upaya Pelestarian LAR Sebagai Padang Pengembalaan Bersama Peternak Tradisional yang Berwawasan Lingkungan di Kabupaten Sumbawa. (Tesis). Program Pasca Sarjana Universitas Diponegoro. Semarang.

Poole, DA. 1982. The effects of milking cows three times daily. Anim Production. 113:197-201.

Saragih. C. I. I.,K. Suada, danI. P. Sampurna. 2013. Ketahanan Susu Kuda Sumbawa Ditinjau dari Waktu Reduktase, Angka Katalase, Berat Jenis, dan Uji Kekentalan. Indonesia Medicus Veterinus. 2(5): $553-561$.

Soryal, K. A., S.S. Zeng, B.R. Min, S.P. Hart and F.A. Beyene. 2004. Effect Feeding System on Composition of 
Goat Milk and Yield of Domiati Cheese. Small Ruminant Research. 54: 121-129.
Sudono A, Rosdiana RF, Setiawan BS. 2003. Kiat mengatasi masalah Praktis; Beternak sapi Perah secara Intensif. Jakarta (ID) Agromedia Pustaka. 